\title{
Exploring the link between forests, traditional custodianship and community livelihoods: The Case of Nyambene forest in Kenya
}

\author{
by Gloria Kendi Borona ${ }^{1}$
}

\begin{abstract}
Kenya is home to many sacred natural sites, including forests, mountains and rivers. Indigenous communities have upheld their role and responsibilities, passed down over centuries by their ancestors as custodians of these places through time. The 5391 hectares in the Nyambene forest in central Kenya is a sacred site to the Ameru people, a community/tribe living on the northeastern slopes of Mt. Kenya. The forest is a resource from which customs, spiritual practices, and governance systems are derived to protect the territory as a whole and maintain its order, integrity and well-being. The Njuri Ncheke (council of elders) play a vital role in upholding the traditional ecological knowledge and customs, practised over generations, including acting as custodians of sacred groves around which rain-making rituals are performed. This paper examines the link between traditional custodianship and community livelihoods against a background of diverse national legislations on forest/land use management and religious influences. The author demonstrates how this forest weaves around the lives of the Ameru people and makes a case for the need to encourage community participation and traditional custodianship in protecting ecosystems and their associated cultural heritage.
\end{abstract}

Keywords: Traditional Ecological Knowledge, community livelihoods, forest resources, traditional custodianship

\section{RÉSUMÉ}

Le Kenya comporte plusieurs sites naturels sacrés comprenant des forêts, des montagnes et des cours d’eau. Les communautés autochtones ont su préserver leurs rôles et leurs responsabilités, hérités de leurs ancêtres au cours des siècles, de gardiens de ces lieux à travers les âges. Les 5391 hectares de la forêt de Nyambene dans le centre du Kenya constituent un site sacré pour la nation Amenu, une communauté tribale qui habite le versant nord-est du mont Kenya. La forêt représente une ressource à partir de laquelle les coutumes, les pratiques spirituelles et les systèmes de gouvernances sont tirés pour protéger le territoire dans son ensemble et pour maintenir son état, son intégrité et son bien-être. Le Njuri Ncheke (le conseil des anciens) joue un rôle important dans le maintien des connaissances écologiques et des coutumes traditionnelles pratiquées au cours des générations, ce qui comprend le rôle de gardiens des terres sacrées sur lesquelles les rites d'invocation de la pluie sont performés. Cet article étudie le lien entre la garde traditionnelle des terres et la vie communautaire par rapport aux différentes législations nationales sur la gestion des forêts ou du territoire et à l'influence de la religion. L'auteur démontre comment cette forêt est intégrée à la vie de la nation Ameru et souligne la nécessité d’encourager la participation communautaire et la garde traditionnelle des terres pour la protection des écosystèmes et du patrimoine culturel.

Mots clés : connaissance écologique traditionnelle, vie communautaire, ressources forestières, garde traditionnelle des terres

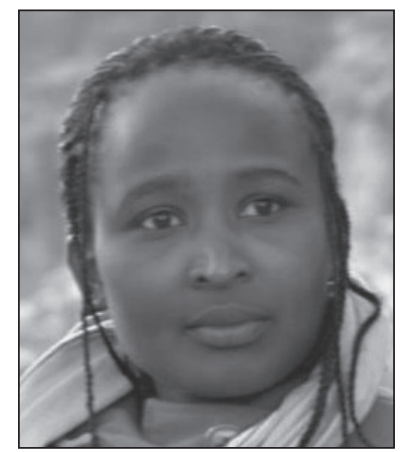

Gloria Kendi Borona
This paper is based on the author's own reflections and experiences formed through growing up adjacent to the Nyambene forest in central Kenya.

\section{Introduction}

The history of traditional forest conservation in Kenya goes back centuries, if not millennia, and is as old as the communities who have depended on it. Prior to the introduction of the current protected area system of conservation, local and traditional institutions regulated and controlled forest resources, ownership, access, and exploitation patterns. Traditional management systems were anchored on precise control instruments and mechanisms embedded in shared norms, values and regulations that were based on community-specific customary laws. These rules and regulations governing resource exploitation promoted sustainable resource use and environmental conservation (Odera 2004). Maathai (2007) argues that in the past unwritten, informal, and systematic taboos, rituals and rules regulated interactions between individuals and the natural environment. Nevertheless, since the introduction of formal management systems, traditional and local mechanisms of forest management have eroded.

Communities assigned spiritual significance to specific regions referred to as "sacred sites" that Adam describes as "places within ecosystems, such as forests, mountains, rivers, and water

${ }^{1}$ Faculty of Forestry, University of British Columbia, Forest Sciences Centre, 2424 Main Mall, Vancouver, British Columbia. E-mail: kendigloria@yahoo.com 
sources, which exist as a network embedded within a territory and for which there are associated spiritual values"(Adam 2012: 9). In addition to the spiritual values these sites are considered to be of great cultural significance for various reasons, including the belief that they are home to the community's ancestral spirits. They are akin to temples or churches and are the focal point for conducting rituals and ceremonies (Adam 2012). Sacred sites the world over have been protected through application of Traditional Ecological Knowledge (TEK) that hinges on the beliefs of specific communities. TEK refers to the knowledge and insights acquired through extensive observation of natural phenomenon and intricate and intimate relationship with natural resources (Christensen 2014). Communities that practice TEK are strongly rooted to the lands that sustained their ancestors and employ time-tested landscape management practices through drawing on sophisticated and complex understanding between people and the spiritual, cultural and environmental dimensions. The term "indigenous people" has been used to refer to such communities. I begin by discussing the positioning of TEK in international law and discourse as well as the prevailing challenges in its application. Following this, I highlight my personal connection to the forest and demonstrate how the forest is intricately tied to community livelihoods. The next section presents other examples of successful application of customary governance in the Kenyan context. A discussion on the positioning of TEK and traditional custodianship in Kenyan legislation follows. Finally, I conclude by making a case for community involvement in resource conservation, the application of TEK and other forms of cultural heritage in crafting resource use and conservation strategies.

\section{TEK in International Discourse}

Proponents of TEK have promoted its integration into the management of natural resources, more so in the last two decades at the local and international scale, especially in the face of escalating environmental crises. The 1987, the Brundtland Commission report recognized the interdependence of the ecological, and humans political-economic systems as key towards addressing the planet's environmental problems and achieving sustainable development. The commission asserted that "Tribal and indigenous peoples' lifestyles can offer modern societies many lessons in the management of resources in complex forest, mountain and dry-land ecosystems...These communities are the repositories of vast accumulations of traditional knowledge and experience that link humanity with its ancient origins. Their disappearance is a loss for the larger society, which could learn a great deal from their traditional skills in sustainably managing very complex ecological systems" (United Nations 1987: 19, 98).

The 1992 "Earth Summit" in Rio de Janeiro yielded several international agreements that guide policy directions for sustainable development. Embedded in these agreements (including in the guiding principles on forests) is the recognition of the explicit role of indigenous communities. Other international conventions, such as the 2008 UN Declaration on the Rights of Indigenous People and the 2003 UNESCO Convention of Safeguarding Intangible Cultural Heritage as well as the UNESCO Convention on the Protection and the Promotion of the Diversity of Cultural Expression (of which Kenya is a signatory), have been ratified relating to the protection of indigenous peoples' intellectual and cultural property and recognizing their distinctive spiritual relationship with their traditional territories.
The Rio +20 conference stressed the importance of the participation of indigenous peoples in the achievement of sustainable development and recognized the United Nations Declaration on the Rights of Indigenous Peoples in the context of global, regional, national and sub-national implementation of sustainable development strategies (United Nations 2012). In the Kenyan context the rights of communities and a furtherance of their respective ways of life are recognized in the 2010 national constitution and other pieces of legislation related to the management of resources discussed later in this paper. Despite all these efforts at both the local and international scales, TEK has not received the recognition that it deserves in the management of resources. While several examples illustrate the effectiveness of applying TEK in resource management contexts, wider application of TEK-derived information remains elusive and inadequate. In part, this is due to continued inertia in favour of established scientific practices and the need to describe TEK in western scientific terms (Huntington 2000).

Despite their importance, sacred sites and territories in Kenya, and indeed across Africa, are faced with increasing threats of destruction from economic and other developments that have contributed to the successive erosion of customary governance systems of their custodial communities (Adam 2012). However, there are still small areas in some regions where respect for ecosystems and application of traditional governance systems have survived, such as in ritual practices that perpetuate communion with the ancestral spirits.

In the following section I discuss a case study of the Nyambene forest in central Kenya, the traditional territory of the Ameru tribe/community to which I belong. The discussion positions the Nyambene forest in the larger cultural landscape in central Kenya and highlights the role of the Njuri Ncheke as custodians in the conservation of the forest resources, including the sacred groves where rain-making rituals are performed.

\section{The Nyambene Forest in Central Kenya}

I was born and raised on the northeastern slopes of Mount Kenya. At 5199 metres, Mount Kenya is the highest mountain in Kenya and the second-highest in Africa after Kilimanjaro in neighbouring Tanzania. The mountain holds spiritual significance to the Agikuyu, Ameru and Aembu communities living around its slopes. "Whether gazing down from the glaciercovered summits over afro-alpine moorlands, diverse forests and fertile farmland to the surrounding plains, or marveling at the snow-tipped peaks rising exactly on the equator from the hot lowlands, you will definitely feel Mount Kenya to be one of the most impressive landscapes in the whole of Africa. That makes it easy to understand why the Kikuyu, Meru and Embu people living in the vicinity regard it as a holy mountain, deified in traditional rituals, prayers and sacrifices." (Fifty Treasures of Kenya n.d.).

The Ameru people refer to Mount Kenya as Kirimara (meaning, glittering mountain/mountain of the splendor) and consider it to be the dwelling place of Ngai/God, which makes it a potent sacred cultural landscape. In essence, the Ameru, as well as the aforementioned communities, believed that as long as the mountain stood, God was with them and they would not want for anything. All good things, such as abundant rain, rivers and streams, flowed from the mountain and for agricultural communities reliable rainfall and availability of water is critical to survival and prosperity. I remember my grandmother's constant reference to Ngai o Kirimara/God of Mount Kenya 
whenever something catastrophic happened or there was any form of crisis in the community. Mountains feature prominently in the oral tradition of the Ameru people's stories of origin, which explain how they escaped from a land where they were held captive by an oppressive kingdom. As the story goes, their prophet Koome Njue communed with God in the mountain several times and asked for guidance on how to respond to the captors' demands for tasks they had to perform in order to secure their freedom. Through their immense pain, suffering and protracted battles, their God in the mountain never failed them. It was through divine intervention that they outwitted their captors and crossed a large body of water known as iria itune/red lake through magical means. ${ }^{1}$

In addition to Mount Kenya, the Nyambene forest situated in the Nyambene range, which rises to an altitude of 2514 metres, is of great spiritual significance to the Ameru people especially those living in what was formerly administratively known as Meru North District and later on Nyambene District and now part of the larger Meru County. The Nyambene range dominates the topography of this region and creates the diversity of the physical landscape, which in addition to the nearby Mount Kenya, influences the climatic conditions. So tied to the community's way of life was the Nyambene range and forest that as soon as a child was born the mother would perform a ritual facing the ranges and offer the child to God.

I spent most of my early years living in a village that was adjacent to this forest and this is my ancestral home. The Nyambene forest, known locally as Njaambene, is 5391 ha of indigenous forest that is intricately linked to Ameru spirituality. Like all other forests in Kenya the forest was managed by the Ameru people through customary law prior to the introduction of formal forest management during the colonial period (1895 to 1963). Although the forest is currently managed by the Kenya government through the Kenya Forest Service, the local community still regards the forest as a hallowed landscape and rain-making rituals, prayers, and other cultural activities are still performed in the forest. The forest provokes a resurgence of our coherent traditional knowledge and customary laws that carry the evolutionary signature of many centuries of resource management that directly links to community livelihoods.

The Ameru are one of more than 42 different ethnic communities/tribes found in Kenya. Their language is Kimeru and they practise agriculture and animal husbandry as the two main modes of subsistence. Land is therefore key to the community's life. It secures for them that peaceful tillage of the soil that is central to their livelihoods. In addition to the formal governance systems instituted by the Kenyan state the Ameru people have retained a traditional jurisdictional system of governance known as Njuri Ncheke, which is one of the defining elements of Ameru society. While other traditional ways of life that defined their ways of life have successively disintegrated in the recent decades as result of colonialism, Christianity, westernization and cash-based economies, the Njuri Ncheke has survived and thrived.

\footnotetext{
${ }^{1}$ The Ameru have one of the most intriguing, baffling histories and mythology of any tribe in Kenya. The generally accepted (although controversial) history recounts they were once enslaved in what is now believed to be Egypt from which they had an exodus and migrated to their present land. The story is strikingly similar to the biblical account of the Exodus.
}

\section{The Njuri Ncheke}

Njuri Ncheke literally translates to "narrow jury" and it is the pinnacle of the Ameru traditional judicial system. It has a maleonly membership and is the highest social rank to which a Meru man could aspire, more so in the past when entry into the council was much more highly restricted and rigorous. ${ }^{2}$ Membership to the council is restricted to elders of absolute integrity and maturity, those that command high respect at the community level, possess great wisdom, an intricate knowledge of the traditions, impeccable self-discipline and honesty. This is important because they are involved in performing functions for which credibility is crucial.

The roles of the Njuri Ncheke include settlement of disputes, creating and executing tribal laws, acting as custodians of tribal culture, regulating the use and conservation of open grasslands, salt-licks, sacred sites and forests. The latter function involves making decisions regarding protection of indigenous tree species, inter-planting trees with crops and conserving indigenous sanctuaries. The Njuri Ncheke is the only traditional judicial system recognized by the Kenyan state through the 2010 constitution. For this reason the Njuri Ncheke wields a lot of political influence among the Ameru people and by extension in Kenya mainly due to their astute and strategic political organization.

Bound by a strict oath of secrecy, the revered Njuri Ncheke, which has for centuries been the preserve of tough-talking elderly men, commands respect, awe and fear in equal measure. Membership in the council involves swearing an oath in a ceremony conducted at sacred shrines. The only aspect of this oath that is public knowledge is the promise to uphold absolute integrity. Failure to adhere to the oath is severely punished through one or more curse(s).

\section{Rain-making Rituals in the Nyambene Forest}

The Njuri Ncheke has been the custodian of this forest and the sacred groves around which rituals and sacrifices have been performed for centuries. Cutting of trees or any other vegetation around these groves is strictly prohibited, which has subsequently preserved them through time. Rain-making rituals are performed if rain fails to fall at the usual time, when people prepare the fields for planting, and drought is imminent. This ritual entails sacrificing a lamb of one colour without any spots or blemishes. Other components include honey and millet. The overnight rituals are performed at sacred groves by chosen elders. Elders emerge from the forest the following day and if the sacrifice is accepted the community is blessed with rainfall.

It is worth noting that sacrifices are also performed for other purposes that are not related to rain-making; for example, when there are epidemics or other happenings that concern the wider community. When sacrifices are not accepted bizarre things can occur. In 2013, my grandmother told me of a recent event (in 2012) where a group of elders went to offer sacrifices that backfired. She told me that God rejected the sacrifice and the sacrificial sheep disappeared only to be found very far away from the forest and no one would touch that sheep. In addition, the elders got lost in the forest and only emerged after a week.

\footnotetext{
${ }^{2}$ This is not to say that anyone can now become a member but the council now seems to be opening up to younger Meru men and politicians as well as elites. This move has elicited criticism from some quarters especially those who believe that this will eventually weaken/ dilute the council.
} 
Why did they get lost? God closed their eyes and they could not find their way out of the forest!

These religious rites and hallowed traditions are not as widespread as was in the case in the past. The fact that my grandmother told me about this in 2013, however, is a clear testament that these practices have persisted to the present despite the extensive Christianization of this region, which results in communities abandoning their traditional spirituality and embracing the Bible. However, when I talk to my grandmother I sense a great hope and witness a rejuvenation of all the collective wisdom of our ancestors over the years. This encourages me to tell my story, a story of how a forest and the environmental services it provides changed my life.

\section{My Personal Connection to the Nyambene Forest}

The Nyambene forest and its sacred groves are a very important water catchment and rivers that flow downstream provide water for at least 500000 people. I am one of the beneficiaries of the preservation of this forest and the associated water catchments. I firmly believe that it is as a result of the waters flowing from this forest that I got an education without great struggle. Water is a game-changer in a woman's life in any rural context in Kenya and, indeed, Africa. Women spend huge amounts of time fetching water and there is not much time left for personal advancement such as education.

I vividly remember the first time I had to go and fetch water. One day, I happily joined my auntie who was helping my mother take care of us at the time. She carried a 20-litre jerrican and handed me a 2-litre container and down the hill we went to the nearest river less than a kilometre away. I carried the water and rested several times along the way but I was extremely exhausted and frustrated by the time we got home. My auntie could not understand why I was "dragging" myself around and "wasting time" by resting after what looked like every five steps! It was an uphill task after all and I was perhaps six or seven years old at the time and I remember thinking "life is going to be very difficult for me from now onwards." With a sense of defeat, I resigned to my fate. This was my introduction to the hardships of life as a woman in my community. Fetching water is just one of the plethora of tasks expected of girls or women in my community.

My lucky break came when we got running water installed in our homestead soon after that experience and that is how I narrowly escaped from a life of carrying 20-litre containers of water for kilometres like many other women have to do. The source of this water was the Nyambene forest. It is because of the water flowing from this forest that I could dedicate sufficient time to education and create a life for myself and not jeopardize my future. For this reason, I am passionate about the conservation of forest ecosystems, especially through incorporation of traditional ecological knowledge/indigenous knowledge systems. It is very personal to me and the person that I have become. The waters flowing from this forest have given me an opportunity to live life in all its fullness and given me a chance to take advantage of opportunities as they are presented.

It is cliché to say that "water is life" but you cannot truly appreciate this fact until you have experienced water scarcity. If there is no water or if you have to spend five hours or more a day searching for water you will face adverse impacts on all aspects of livelihoods. Water, and in extension forests, count for everything. However, the Nyambene forest and the Ameru people are not the only examples of the close link between TEK and forest and community livelihoods in Kenya. Other examples are presented in the next sections.

\section{Sacred Mijikenda Kaya Forests in the Kenyan coast}

The Mijikenda Kaya forests are home to numerous fortified villages known as kayas of the Mijikenda people (another of the 42 Kenyan tribes). The Mijikenda revere these forests as sacred sites and regard them as the homes of their ancestors. The forests are managed through collaborative efforts between the Kenya government and the Mijikenda council of elders. The forests around the kayas have been nurtured by the Mijikenda community to protect the sacred graves and groves and are now almost the only remains of the once extensive coastal lowland forest. These forests were inscribed into the UNESCO World Heritage List in 2008 for bearing a unique testimony to a cultural tradition and for their direct link to a living tradition. The kayas provide focal points for Mijikenda religious beliefs and practices and are intricately linked to the community's identity. These forests have only been saved through the application of restrictions for utilization of forest resources by the council of elders.

\section{Poaching}

There has been an escalating crisis of poaching in Kenya in the last five years. In the first six months of 2013 more than 7.5 tons of ivory was seized in the country. This is more than was seized in the whole of 2012 (Kahumbu 2013). Stiffer penalties, investment in technology such as drones and a horde of other measures have not made any significant contributions to reverse the trend. At the same time, leading conservation organizations are advocating an approach that seeks to integrate traditional governance systems in solving this crisis. Kahumbu (2013) argues that traditional courts have been shown to be effective for wildlife crimes by citing an example from May 2013 when poachers came forward and owned up to their crimes only when traditional methods were employed despite previous attempts by the government. While this is only one isolated example it is still demonstrates that traditional methods could provide answers to some of the quagmires we find ourselves in Kenyan society. "As Kahumbu astutely argues "There is need to recognize and empower traditional African courts to honour African values, change perceptions and grow a community that defends elephants despite the economic incentives" (Kahumbu 2013).

From the above case studies it is clear that TEK is an important tool that can be used in the conservation of resources in the Kenyan context. Does application of TEK and traditional custodianship align with policy in Kenya? In the next section I discuss the positioning of traditional custodianship in the management of forest ecosystems in Kenya.

\section{Kenyan Forest Policy and Traditional Custodianship} Kenya boasts the most diverse forest ecosystems in East Africa, comprising coastal, rain, riverine and montane forests that are biologically diverse and contain numerous local endemic species. There are five major forest ecosystems known as "water towers" in the country: Mau Forest Complex, Mount Kenya, the Aberdare, Mount Elgon and Cherangani. These forests deliver vital services such as clean water, timber, fuel, and food directly 
to rural communities. In Kenya, over $90 \%$ of all water comes from these forested mountains and $70 \%$ of electrical power generation is derived from rivers that flow from these forests (UNEP 2009).

From the late 1970 s to the early 1980s there was an unprecedented acceleration in the destruction of forests in Kenya, which to a large extent was blamed on the lack of an appropriate and all-inclusive forest policy and legislation. The policies and legislation used to manage forest resources were developed in 1957 by the colonial government and changed only slightly after independence in 1968 (KFS 2007). This approach to forest governance was largely considered to be repressive and inconsiderate to less advantaged members of the various communities living in Kenya. Thus, local communities yearned for policies and laws that would recognize and include them in the governance of the country's forests.

Forest management in Kenya has been driven by two categories of management philosophies, the utilitarian and the preservation approach. In principle the utilitarian approach is perceived as an important incentive to conservation, while the latter is a potent disincentive. The underlying principle of the preservationist approach is the exclusion of protected areas from extractive practices. The philosophy behind true conservation is combining sustainable extractive and non-extractive activities in designated forest ecosystems. In most cases both the conservation and preservation approaches lead to local custodians being constrained in respect to access, utilization and control of basic resources that support their livelihood (Mogaka et al. 2001).

In the Kenyan context the new constitution adopted in August 2010 marks a pivotal shift and significantly alters Kenya's socio-cultural, political, legal and economic spheres. The constitution now explicitly requires the government to involve communities in conserving and managing lands and ecosystems, thus opening more space for dialogue and deeper recognition of communities and their respective cultures. This constitution follows other national laws that recognize and encourage community participation in protecting ecosystems, e.g., the National Museums and Heritage Act 2006, Forests Act 2005 (emphasis added), the Forests (Participation in Sustainable Forest Management) Rules 2009, the Environmental Management and Coordination Act 1999 and Environmental Management and Co-ordination Regulations 2006 (Adam 2012).

After decades of state-led forest management in Kenya, Kenya has undergone a major change through the operationalization of the Forests Act 2005. The Act creates an opportunity for communities to be involved in forest management through Community Forest Associations (CFAs), embracing the participatory forest management approach. The Forest Act 2005 has been welcomed as a paradigm shift from command-andcontrol towards greater participation in forest management and conflict resolution over forest resources. The CFAs are an opportunity to marshal key stakeholders (forest communities) in the management and conservation of forests (Ongugo 2007). The policy is underlined by integrated management, traditional and cultural values (emphasis added), stewardship, community participation, user pays principle, intra and inter-generational equity, market value of forest products and international cooperation (KFS 2007).

CFAs safeguard forests through protection and conservation activities. In exchange they are expected to receive timber and non-timber products as well as revenue from community-based industries, ecotourism, recreation, scientific and educational activities. This community engagement model is expected to contribute to poverty reduction, employment creation, improvements of livelihoods through sustainable use, conservation and management of forests.

According to Ongugo (2007) there is vast potential in the indigenous knowledge of the members of the CFAs since they have lived in and adjacent to the forest for a long time. The elders in the community often know the tree species in the forest, their uses, abundance and diversity. Such knowledge is important in education, research and ecotourism. This, in addition to other local knowledge on timber and non-timber products, can position the community better as co-managers of the forest ecosystems with the Kenya Forest Service.

\section{Conclusion}

The case of the Nyambene forest is a clear testament that culture has not been completely annihilated by colonialism, religion and oppressive governance regimes or simply the general apathy of humankind. This in itself is something worth celebrating and discussing in an effort to bring TEK to the heart of development and conservation discourses in Kenya, Africa and the world at large. It is worthwhile to hold on to whatever little glimmers of hope exist as they offer powerful and potent starting points from which communities can engage with different stakeholders on resource management.

As evidenced by various international laws and protocols there is growing global consensus that the redesign of development interventions should start by examining local constructions, to the extent that they are the life and history of the people. This implies a change that comes from within communities themselves, having confidence in, and deploying, indigenous knowledge to help bring about economic and social progress (UNESCO and NUFFIC 2002). Integration and recognition of TEK can ensure ecological and cultural continuity in the face of change and will help communities to strengthen their traditional practices and knowledge systems while developing sustainable societies (Christensen 2014).

Maathai (2010) argues that perhaps the most unrecognized problem in African today is disempowerment. The systematic extermination of the many good aspects of Africa's culture has undoubtedly led to the strategic disempowerment of African societies. Communities should have a right to honour and practice their cultures and make them relevant to today's needs. As Maathai (2010) poignantly notes “The challenge for many parts of Africa that were de-cultured is to discover their cultural heritages and use them to both connect with the past and help direct them in their political, spiritual, economic and social development. Let us practise our spirituality and dance our dances, revivify our symbols and re-discover our communal character. Without these cultural acts we are vulnerable to anyone who wishes to exploit us."

The world stands at a cross-road in search of a new vision of development that is truly sustainable, especially in the face of global concerns like climate change. International and national institutions, in the case of Kenya, are seeking to promote development paradigms that build on knowledge resources that exist among communities. There is growing consensus that the use and promotion of scientific methods of forest conservation alone is not sufficient. Perhaps the answers to the environmental challenges we face lie with communities and within knowledge embedded in TEK and other local knowledge systems working 
with scientific management regimes. This calls for honest engagement with local communities in a constructive manner in order to create common ground and long-term solutions. The academic community can contribute to the process through undertaking research to better understand the role and potential of TEK in forest management in the African context and other areas where environmental resources remain a sophisticated pedestal around which culture, religion, livelihoods and governance are constructed.

\section{References}

Adam, A. 2012. Recognising sacred natural sites and territories in Kenya: An analysis of how the Kenyan constitution, national and international laws can support the recognition of sacred natural sites and their community governance systems. Available at https://cmsdata. iucn.org/downloads/gaiasns_1.pdf [Accessed 20 April 2014].

Christensen. 2014. Australia: Heading back to homelands. Available at http://www.christensenfund.org/2014/04/08/australia-homelandsmovement/ [Accessed 8 April 2014].

Fifty treasures of Kenya. n.d. Mount Kenya and Nyambene hills. Available at http://www.50treasuresofkenya.org/mount-kenya-nyambene-hills [Accessed 25 April 2014].

Huntington, H. P. 2000. Using traditional ecological knowledge in science: methods and applications. Ecological Applications 10(5): 1270-1274. Available at http://www.fws.gov/nativeamerican/pdf/tekhuntington-2000.pdf [Accessed 15 April 2014].

Kahumbu, P. 2013. Guns will not win the war against elephant poachers. Available at http://www.theguardian.com/environment/africa-wild/2013/jul/09/guns-war-elephant-poachers [Accessed 20 April 2014].
[KFS] Kenya Forest Service. 2007. Participatory forest management guidelines. Kenya Forest Service, Nairobi, Kenya.

Maathai, W. 2007. Unbowed: One woman's story a memoir. Random House Inc, New York.

Maathai, W. 2010. The challenge for Africa. Random House Inc, New York.

Mogaka, H., G. Simons, J. Turpie, L. Emerton and F. Karanja. 2001. Economic aspects of community involvement in sustainable forest management in sustainable forest management in eastern and southern Africa. Available at http://www.cbd.int/financial/values/geconomicafrica-iucn.pdf [Accessed 15 April 2014].

Odera, J. 2004. Lessons Learnt on Community Forest Management in Africa. Report for project 'Lessons Learnt on Sustainable Forest Management in Africa'. National Museums of Kenya in conjunction with KSLA/AFORNET/FAO.

Ongugo, P.O. 2007. Participatory forest management in Kenya. Is there anything for the poor? Available at http://www.mtnforum.org/ sites/default/files/publication/files/4937.pdf [Accessed 22 July 2014].

[UNEP] United Nations Environmental Programme. 2009. Kenya: Atlas of our Changing Environment. UNEP, Nairobi, Kenya.

[UNESCO and NUFFIC] United Nations Educational Scientific and Cultural Organization and Netherlands Organization for International Cooperation.2002. Best practices using indigenous knowledge systems. Available at http://www.unesco.org/most/Bpikpub2.pdf [Accessed 02 February 2014].

United Nations. 1987. Our common future. Available at http://upload.wikimedia.org/wikisource/en/d/d7/Our-common-future.pdf [Accessed 20 April 2014].

United Nations. 2012. The future we want. Available at http://sustainabledevelopment.un.org/future wewant.html [Accessed 20 April 2014]. 